\title{
IBM KELOMPOK PETERNAK SAPI PERAH DI BENDUL MERISI KELURAHAN BENDUL MERISI, KECAMATAN WONOCOLO, KOTA SURABAYA
}

\section{(APPROPRIATE TECHNOLOGY GROUP IN THE DAIRY FARMERS IN THE BENDUL MERISI VILLAGE, WONOCOLO DISTRICT, SURABAYA).}

\author{
Bambang Gunawan ${ }^{1)}$ dan Nurlina ${ }^{2)}$ \\ 1,2) Fakultas Pertanian, Universitas Merdeka Surabaya \\ e-mail : gunawanb1011@gmail.com
}

\begin{abstract}
Potential products fresh milk from a partners dairy farmers in the area Bendul Merisi Surabaya is still quite favorable, but the technology has not been used in terms of addressing the problem of livestock waste, so the existence of the business partners still largely very simple in handling the waste, which could impact unhealthy society around. The existence of farm businesses that are geographically dense settlements which are urban areas in Surabaya, where villagers are a mixture of local women for newcomers. Required touch technology and knowledge in the group of dairy farmers are still traditional, thus providing added value to the farm business that is expected to have an impact on the surrounding environment healthier.
\end{abstract}

In the implementation of community service (PPM) is made to partners I, namely Mr. Masoud located in the Bendul Merisi, 27 Surabaya and partners II, Mrs. Aslam in the Bendul Merisi, 31 Surabaya, both within the village RW.6 RT.5 Bendul Merisi Wonocolo Subdistrict Surabaya. Priority issues in general partners after advocacy by Tim PPM states have realized the importance of livestock wastewater treatment so as not to impact negatively on the environment and understand the importance of fresh milk production management by developing a broader market access (internet media).

The purpose of this devotion 1). provide a good understanding of the handling of liquid waste from the farm; 2). provide a good understanding of marketing management of fresh dairy products; 3). develop household business partners who are economically independent. The method is offered for problems of waste and management are 1) helping to prepare the handling and management of liquid waste effectively is by building bathtub tiered so that the water coming out of the location of the farm is quite clean and does not pollute the environment, 2) help increase the marketing management product by utilizing Internet access.

By the conclusion of $2016 \mathrm{IbM}$ have done the steps are 1) the innovation of science and technology in the form of construction of wastewater treatment basin farms in stages; 2) advocacy to partner in improving the understanding of appropriate technology and 3) to facilitate the implementation of Internet technology to expand its internet blog marketing information and business networks. With these steps, the partners feel the positive benefits such as ease of access to fresh milk sales and the emergence of consciousness and moral responsibility for pollution of river water in view of the farm is located in a densely populated urban environment Surabaya.

Keywords : dairy farm, handling wastewater, assistance

\section{PENDAHULUAN}

Usaha peternakan sapi perah dengan skala usaha lebih dari 20 ekor dan relatif terlokalisasi akan menimbulkan pencemaran terhadap lingkungan. Pencemaran ini disebabkan oleh pengelolaan limbah yang belum dilakukan dengan baik, tetapi kalau dikelola dengan baik, limbah tersebut memberikan nilai tambah bagi usaha peternakan dan lingkungan di sekitarnya. Limbah peternakan adalah semua buangan dari usaha peternakan yang bersifat padat, cair dan gas. Limbah padat merupakan semua limbah yang berbentuk padatan atau dalam fase padat (kotoran ternak, ternak yang mati atau isi perut dari pemotongan ternak). Limbah cair adalah semua limbah yang berbentuk cairan atau berada dalam fase cair (air seni atau urine, air pencucian alat-alat). Sedangkan limbah gas adalah semua limbah yang berbentuk gas atau berada dalam fase gas. Menurut Juheini (1999), sebanyak 56,67 persen peternak sapi perah membuang limbah ke badan sungai tanpa pengelolaan, sehingga terjadi pencemaran 
lingkungan. Pencemaran ini disebabkan oleh aktivitas peternakan, terutama berasal dari limbah yang dikeluarkan oleh ternak yaitu feses, urine, sisa pakan, dan air sisa pembersihan ternak dan kandang. Adanya pencemaran oleh limbah peternakan sapi sering menimbulkan berbagai protes dari kalangan masyarakat sekitarnya, terutama rasa gatal ketika menggunakan air sungai yang tercemar, di samping bau yang sangat menyengat. Pengelolaan limbah yang kurang baik akan menjadi masalah serius pada usaha peternakan sapi perah. Sebaliknya bila limbah ini dikelola dengan baik dapat memberikan nilai tambah. Salah satu upaya untuk mengurangi dampak limbah adalah mengintegrasikan usaha tersebut dengan beberapa usaha lainnya, seperti penggunaan suplemen pada pakan, usaha pembuatan kompos, budidaya ikan, budidaya padi sawah, sehingga menjadi suatu sistem yang saling sinergis.

Di Kelurahan Bendul Merisi, khususnya wilayah Bendul Merisi, 27 Surabaya; Bendul Merisi, 31 Surabaya Kecamatan Bendul Merisi Kota Surabaya Jawa Timur terdapat kelompok peternak sapi perah, dimana jumlah Jumlah sapi yang dipelihara oleh dua orang mitra sebanyak 62 ekor sapi dan usaha ini sudah berlangsung lama dan turun temurun dari kakek neneknya pada anaknya yang sekarang pada generasi ketiga. Dalam pemeliharaan sapinya kondisi fisik kandang sudah tertata dan tersedia sumber air bor yang setiap saat digunakan untuk pembersihan kandang-kandang dan sapinya; namun ironisnya penanganan limbahnya belum dilaksanakan secara profesional, akan tetapi masih bersifat tradisional yaitu mencairkan limbah padat lalu mengalirkan langsung ke parit kecil dalam lokasi peternakan, selanjutnya air keluar dari lokasi peternakan begitu saja langsung ke sungai sehingga dimungkinkan adanya dampak pendangkalan sungai serta bau yang ditimbulkan yang dapat menganggu kenyamanan warga sekitar. Kemudian produk susu yang dihasilkan sebanyak kurang lebih 200 liter per hari dan secara tehnis hasil susu dijual di wadah botol-botol sebagai susu segar dan asli serta diambil agen untuk diperjualbelikan di wilayah kota Surabaya mengingat permintaan susu segar semakin meningkat. Data dari Gabungan Koperasi Susu Segar Indonesia (GKSI) Jawa Timur, bahwa tahun 2014 produksi susu segar Jawa Timur meningkat $15 \%$ yaitu 1,15 juta liter per hari dari tahun 2013 sebesar 1000 ton atau 1 juta liter per hari; sementara kebutuhan susu sapi segar di Jawa Timur sebesar 1,7 juta liter per hari dan produk susunya hanya sebesar 1 juta liter per hari, sehingga terdapat defisit sevbesar 700 liter per hari. Hal ini masih menjadi daya tarik tersendiri bagi pengembangan kewirausahaan di Kelurahan Bendul Merisi dan Kelurahan-kelurahan lainnya di Kota Surabaya selama ini, dimana jumlah sapi perah produktif yang tercatat dalam asosiasi Gabungan Kelompok Peternak Sapi (Gapokpi) di Kota Surabaya masih sebesar 517 ekor tahun 2013 yang mengalami penurunan dari sejumlah 1.427 ekor tahun 2011 (Dinas Peternakan Kota Surabaya, 2013). Potensi inilah perlu adanya dukungan teknologi tepat guna dari Fakultas Pertanian Universitas Merdeka Surabaya sebagai bentuk pengabdian kepada msyarakat untuk meningkatkan pemahaman manajemen pemasaran dan penanganan limbah peternakan, sehingga kondisi kandang lebih sehat yang dapat berdampak pada kesehatan ternak sapi dan higienis produksi susu tersebut.

Keberadaan peternak yang terdapat dalam wilayah Bendul Merisi Kota Surabaya, dimana jumlah penduduk yang padat dan lokasi pemukiman yang berdempetan secara geografis merupakan suatu wilayah perkotaan di Surabaya, dimana warga kelurahan merupakan campuran antara warga asli daerah dengan warga pendatang sehingga keadaan masyarakat menjadi sangat beragam dalam sudut pandang sosial dan budaya, tetapi dalam mata pencaharian sebagian besar penduduknya adalah pegawai swasta pada beberapa industri dan jasa. Dalam proses pemeliharaan sapi sebagian besar peternak dalam penanganan limbahnya masih menggunakan teknologi atau cara-cara tradisional dengan mencairkan limbah padat lebih dulu kemudian mengalirkan begitu saja cairan yang terbentuk ke parit dan seterusnya menuju sungai, padahal di lingkungan sekitarnya padat penduduknya dan cenderung mencemari sungai, sehingga dalam upaya untuk meningkatkan kualitas air sungai di Surabaya yang juga airnya digunakan sebagai bahan baku air PDAM diperlukan tindakan efektif berupa teknologi penjernihan air limbah melalui tahapan bak-bak pengendapan sehingga air ang keluar dari lokasi peternakan sudah jernih dan tidak berbau. Melalui tindakan atau implementasi teknologi pengolahan limbah ini diharapkan akan meningkatkan kualitas air yang dibuang ke sungai dan berdampak meningkatkan kuantitas produksi susu sapi karena kondisi kandang dan sapi yang lebih bersih.

Para peternak selama ini terus dihadapkan pada situasi persaingan pasar dan selalu berupaya menyelesaikan berbagai permasalahan yang dihadapi supaya dapat tetap eksis mempertahankan kelangsungan usahanya. Salah satu upaya nyata yang dilakukan oleh para peternak untuk 
mendukung perkembangan usahanya adalah melalui pengelolaan tenaga kerjanya agar bisa bekerja lebih efektif dan efisien. Namun demikian, dalam perkembangannya upaya tersebut pun tidak dapat terlaksana dengan baik karena kebanyakan tenaga kerja didatangkan khusus dari daerah karena kebanyakan pekerja dari perkotaan tidak tertarik pada usaha peternakan sapi dan lebih memilih bekerja di sektor industri atau buruh pabrik. Hal ini salah satunya disebabkan para tenaga kerja tersebut memiliki tingkat pendidikan yang rendah, sehingga umumnya kemampuan yang mereka miliki merupakan proses hasil belajar secara mandiri yang menyebabkan pekerjaan yang mereka lakukan pun belum efektif dan efisien.

Berdasarkan kondisi diatas bahwa masalah yang paling menonjol dihadapi oleh usaha peternakan sapi perah khususnya di Jl. Bendul Merisi Surabaya Jawa Timur adalah pengembangan sumberdaya manusia. Pengembangan SDM dititikberatkan pada pemahaman kesehatan lingkungan melalui teknologi penanganan limbah padat maupun cair serta peningkatan kemampuan manajemen pemasaran. Keberadaan peternak sapi di lingkungan masyarakat perkotaan ini dapat menyebabkan dampak lingkungan kurang sehat bagi sekitarnya maupun kondisi kualitas air sungai di Surabaya menjadi tercemar. Permasalahan yang dihadapi mitra adalah : 1). Tidak terdapatnya bak pengolahan limbah yang berasal dari limbah kotoran sapi; 2). Pembuangan limbah kotoran sapi ke parit seterusnya menuju badan sungai; 3). Lemahnya manajemen pemasaran yang dilakukan terkait produk susu segar.

Tujuan kegiatan ini adalah untuk membantu masyarakat khususnya peternak sapi perah di Kelurahan Bendul Merisi, Kecamatan Wonocolo Kota Surabaya untuk meningkatkan kesadaran mitra untuk tidak membuang limbah cair peternakan secara langsung agar tidak menyebabkan pencemaran dan pendangkalan sungai dengan dukungan peralatan dan pembuatan bak limbah, juga meningkatkan akses penjualan susu segar dengan ketersediaan media internet (blogspot) untuk memperluas jaringan pemasaran mitra.

\section{METODE KEGIATAN}

Model yang ditawarkan untuk persoalan limbah dan manajemen adalah : 1). Membantu menyiapkan penanganan dan pengelolaan limbah cair secara efektif agar air yang keluar dari lokasi peternakan tidak mencemari lingkungan. 2). Membantu peningkatan manajemen pemasaran produk susu segar melalui akses internet. Metode yang dilaksanakan untuk mewujudkan model yang ditawarkan, yaitu :

a. Observasi, yaitu melakukan pengamatan langsung untuk mengetahui kondisi riil di lapang.

b. Wawancara, yaitu melakukan tanya jawab kepada mitra untuk mendengar dan mengetahui permasalahan yang dihadapi oleh mitra.

c. Pendampingan dalam manajemen pengembangan akses pemasaran

d. Difusi ipteks yakni implementasi teknologi pengelolaan limbah cair peternakan

Berikut potret mitra secara fisik :
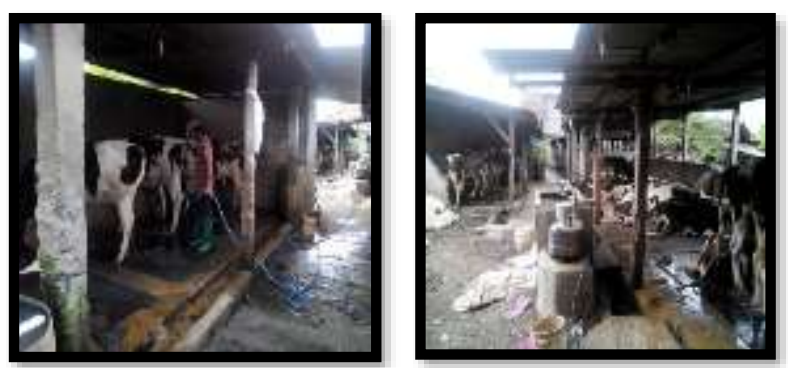

Gambar 1.

Tindakan Pengenceran Limbah padat dan kondisi saluran di Kandang Sapi Milik Peternak Mitra di Bendul Merisi Kota Surabaya

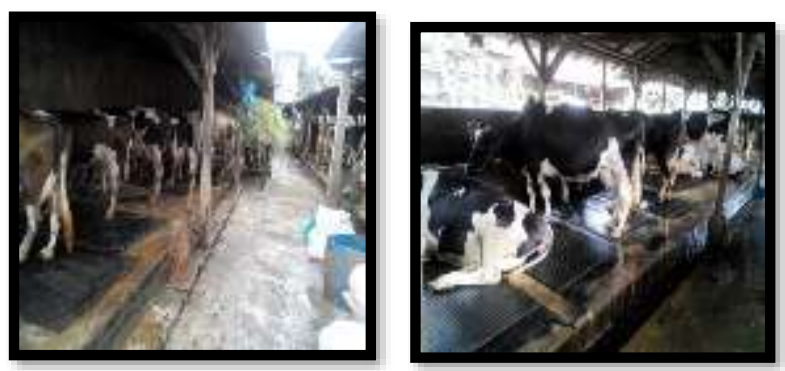

Gambar 2 .

Kandang khusus bagi sapi produktif dan saluran/parit di sekitar kandang sapi milik peternak mitra di Bendul Merisi Kota Surabaya

\section{HASIL DAN PEMBAHASAN}

\subsection{Penanganan Limbah Peternakan Sapi Perah}

Potensi produk susu segar dari usaha peternakan mitra di wilayah Bendul Merisi Surabaya masih cukup menguntungkan, namun belum tersentuh teknologi dalam hal penanganan limbah cair peternakan, sehingga keberadan usaha mitra sebagian besar masih sangat sederhana dalam penanganan limbahnya yang dapat berdampak tidak sehat pada lingkungan sekitar.

Perlu adanya uluran paket teknologi dalam penanganan limbahnya yang didampingi oleh tim dari 
Universitas Merdeka Surabaya. Jadi posisi lembaga dalam hal ini Universitas Merdeka Surabaya memberikan pendampingan paket teknologi penanganan limbah cair serta pendampingan manajemen pemasaran. Sebagai kelompok sasaran dalam hal ini mengambil 2 (dua) mitra usaha, dimana usaha peternakan mitra ini dalam satu lokasi/lahan dan aliran limbah setelah dicairkan dialirkan menjadi satu yang sangat memungkinkan pengelolaan limbahnya disatukan tempatnya.

\subsubsection{Pembuatan Bak Penampungan Berjenjang}

Usaha peternakan sapi di daerah pemukiman atau perkotaan idealnya memiliki tempat pengolahan limbah domestik. Limbah cair yang merupakan hasil pengenceran limbah padat sekaligus bercampur urine diolah melalui berbagai proses untuk menghilangkan atau mengurangi bahan-bahan pencemar (polutan) yang terkandung dalam limbah sehingga tidak melebihi baku mutu. Setelah melalui proses pengolahan limbah bak berjenjang, air limbah yang keluar diharapkan dapat dibuang ke lingkungan dengan aman.

Prinsip dasar kolam atau bak koogulasi adalah pemisahan limbah cair secara berjenjang pada beberapa kolam yang dialirkan melalui grafitasi. Selanjutnya terdapat proses pengendapan dan dekomposisi bahan organik secara alami atau bantuan penambahan organisme dan dipantau dengan bioindikator berupa ikan. Metode ini cukup baik diaplikasikan pada kondisi lapang yang cukup luas sebagaimana pada usaha mitra yaitu dengan pengembangan usaha pemeliharaan ikan. Paket teknologi tersebut disediakan untuk melaksanakan penanganan limbah, selanjutnya diobservasi kualitas air yang dibuang ke sungai, sehingga tidak berdampak pada pendangkalan sungai atau mengganggu kehidupan biota air sungai disamping dampak kenyamanan pada warga sekitar.

Bahan dan Alat pembuatan bak/kolam berjenjang penanganan limbah cair peternakan :

a) Peralatan, antara lain : Cangkul, sekop, pompa air, tenaga tukang dll

b) Bahan, antara lain : Limbah kotoran sapi (yang diencerkan), batu bata, pasir, semen, besi kolom dan tanah urug (sirtu).

\subsubsection{Prosedur Pengolahan Limbah}

a. Tahap Pengolahan Primer (Primary Treatment), yaitu :

- Pertama, limbah yang mengalir melalui saluran pembuangan disaring menggunakan jeruji saring (bar screen). Tujuannya untuk menyisihkan bahan-bahan padat berukuran besar dari air limbah.

- Kedua, limbah yang telah disaring kemudian disalurkan ke suatu bak/penampungan I yang berfungsi untuk memisahkan pasir dan partikel padat tersuspensi lain yang berukuran relatif besar. Endapan partikel tersebut akan membentuk lumpur yang Kemudian akan dipisahkan dari air limbah ke saluran lain untuk diolah lebih lanjut.

b. Tahap Pengolahan Sekunder (Secondary

Treatment)

- Tahap pengolahan sekunder merupakan proses pengolahan secara biologis, yaitu dengan melibatkan mikroorganisme yang dapat mengurai/mendegradasi bahan organic, dengan metode metode kolam perlakuan (treatment ponds/lagoons).

- Limbah cair dari pengolahan primer dialirkan kedalam kolam-kolam terbuka bak penampungan ke-2 dan ke-3. Algae yang tumbuh di permukaan kolam akan berfotosintesis menghasilkan oksigen. Oksigen tersebut kemudian digunakan oleh bakteri aerob untuk proses degradasi bahan organik dalam limbah.

- Selama proses degradasi di kolam, limbah juga akan mengalami proses pengendapan. Setelah limbah terdegradasi dan terbentuk endapan di dasar kolam, maka air limbah dapat disalurkan untuk dibuang ke lingkungan atau sungai.

\section{Skema Penanganan Limbah :}

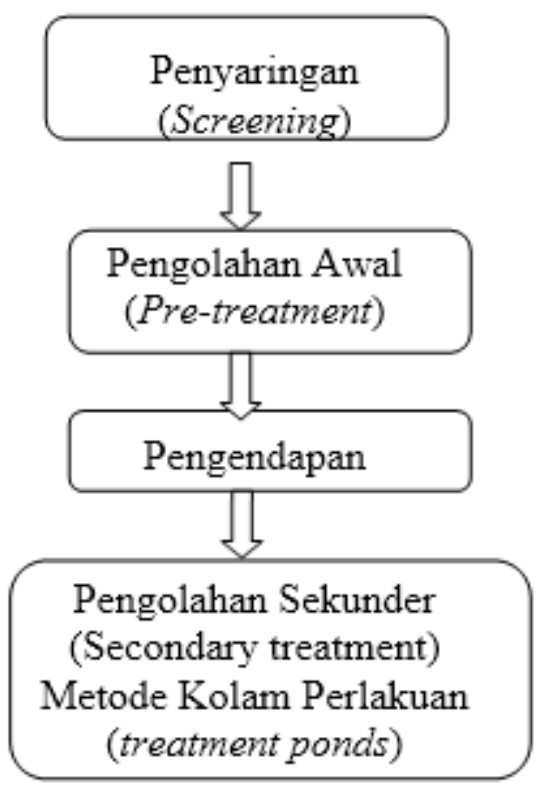




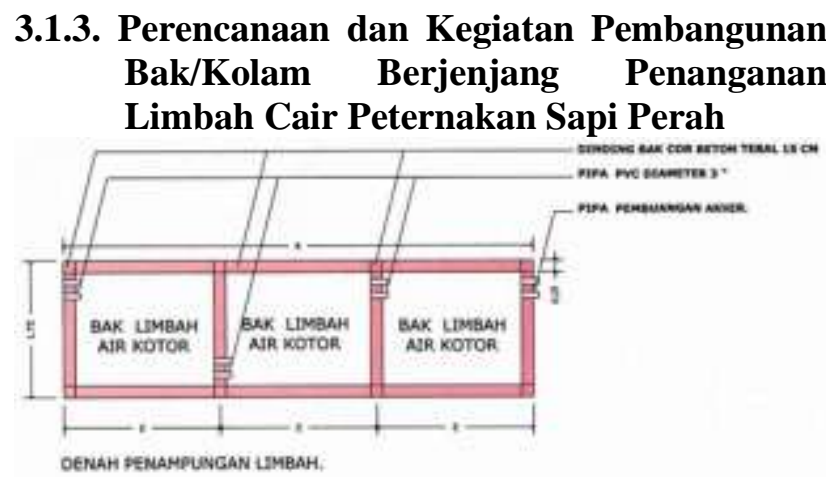

GAMBAR BAK

PENANGANAN LIMBAH CAIR PETERNAKAN.

Gambar 3.

Tampak atas dari gambar perencanaan bak penanganan limbah cair peternakan.

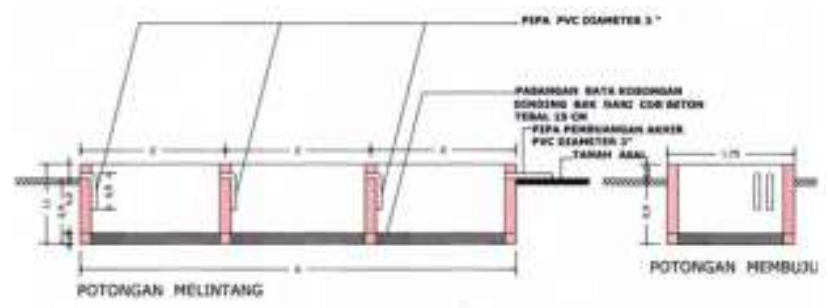

GAMBAR BAK

PENANGANAN LIMBAH CAIR PETERNAKAN.

Gambar 4.

Potongan membujur dari Gambar Bak Penanganan limbah cair peternakan.
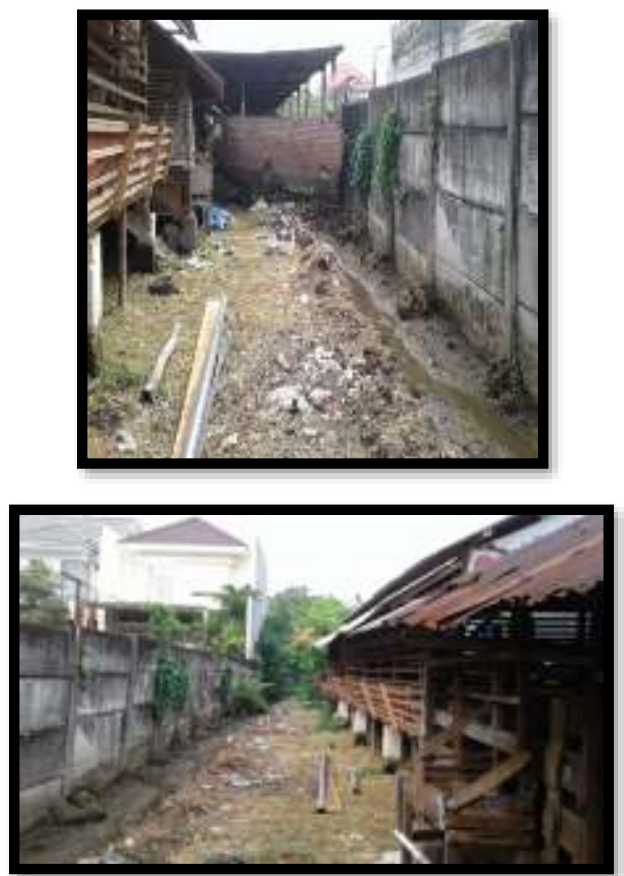

Gambar 5

Lokasi usaha peternakan dan saluran limbah yang dekat dengan pemukiman penduduk.
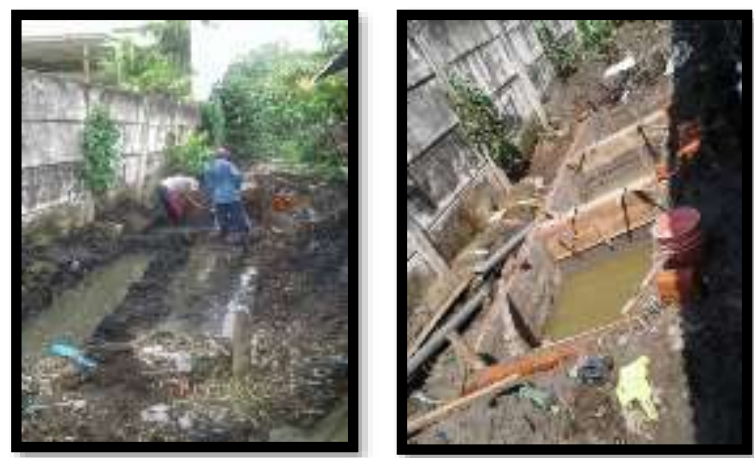

Gambar 6.

Kegiatan penggalian bak/kolam serta kondisi fisik awal bangunan bak berjenjang penanganan limbah cair peternakan.

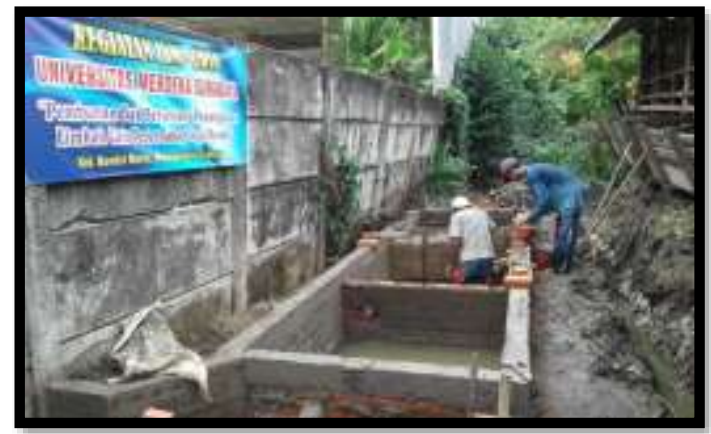

Gambar 7.

Kondisi bangunan bak berjenjang penanganan limbah cair peternakan pencapaian finishing.

\subsection{Manajemen Pemasaran}

Pengembangan manajemen pemasaran dengan ditingkatkannya program-program pendampingan tentang pemasaran serta kerjasama dengan Dinas Peternakan selaku Pembinan Gapokpi dengan dosen Universitas Merdeka Surabaya. Model pemasaran dikembangkan terus untuk menembus pasar lokal lebih optimal dan potensi permintaan yang makin meningkat.

Oleh karena itu pada kesempatan ini akan diimplementasikan paket teknologi guna memperluas informasi produk susu kepada masyarakat luas melalui pembuatan blog informasi dan pemasaran melalui internet guna meningkatkan kemudahan akses dan kuantitas penjualan susu segar. Dengan demikian diharapkan usaha ini mampu membantu peluang bagi berkembangnya usaha kewirausahaan skala mikro bidang peternakan sapi perah tanpa mencemarkan lingkungan sekitar. 


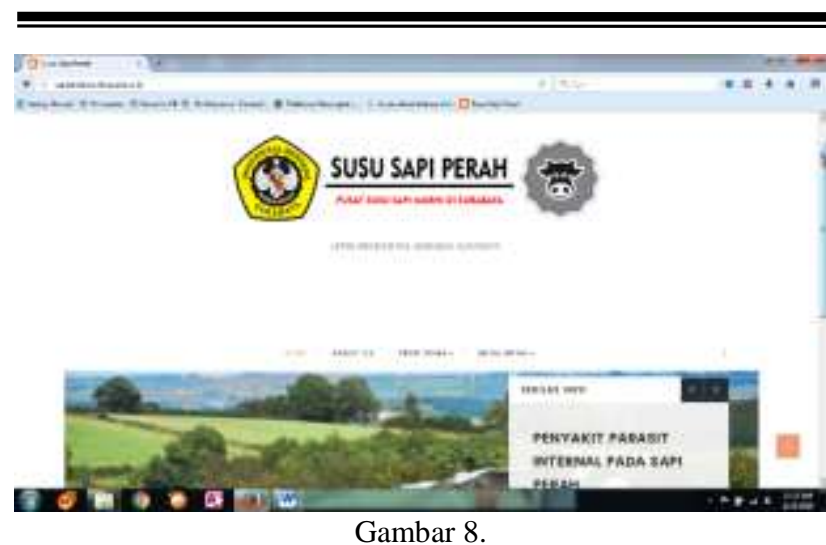

Blog internet sebagai peningkatan akses pemasaran produk susu segar

\subsection{Pembahasan}

\subsubsection{Pengembangan Potensi Mitra}

Pengembangan potensi produk susu segar dari usaha peternakan mitra di wilayah Bendul Merisi Surabaya masih cukup menguntungkan, namun belum tersentuh teknologi dalam hal penanganan limbah peternakan, sehingga keberadan usaha mitra sebagian besar masih sangat sederhana dalam penanganan limbahnya yang dapat berdampak tidak sehat pada lingkungan sekitar. Usaha peternakan sapi di daerah pemukiman atau perkotaan idealnya memiliki tempat pengolahan limbah domestik. Limbah cair yang merupakan hasil pengenceran limbah padat sekaligus bercampur urine diolah melalui berbagai proses untuk menghilangkan atau mengurangi bahan-bahan pencemar (polutan) yang terkandung dalam limbah sehingga tidak melebihi baku mutu. Setelah melalui proses pengolahan, air limbah diharapkan dapat dibuang ke lingkungan atau sungai dengan aman.

Menyadari potensi masyarakat yang bergerak di usaha peternakan masih demikian besar dalam mengembangkan usaha mikro ini, dan Pemerintah kota Surabaya masih menaruh perhatian besar dengan melakukan pembinaan serta pengawasan pada masyarakat setempat dalam bentuk pemberdayaan ekonomi kerakyatan yang diharapkan setiap desa/kelurahan mempunyai spesifikasi unggulan yang dapat diberdayakan potensi ekonominya sehingga masyarakat dapat terdorong untuk semakin mengembangkan produktifitasnya. Ini merupakan salah satu cara untuk mengembangkan potensi warga Kota Surabaya.

Kondisi akhir hasil monitoring pada kedua mitra yaitu Bapak/Ibu Mas'ud maupun Ibu Aslam keduanya memproduksi susu segar dari usaha peternakan sapi perahnya, antara lain :

\begin{tabular}{|c|c|c|c|}
\hline No. & URAIAN & $\begin{array}{l}\text { PRODUK } \\
\text { HARIAN }\end{array}$ & $\begin{array}{l}\text { PRODUK } \\
\text { BULANAN }\end{array}$ \\
\hline 1 & $\begin{array}{l}\text { Bapak/lbu Mas ud selaku } \\
\text { mitra-1 memiliki sapi produlatif } \\
\text { sebanyak } 25 \text { ekor dari } 60 \text { ekor } \\
\text { sapi seluruh miliknya dan } \\
\text { mampu menghasilkan antara } 5 \text {. } \\
10 \text { liter per ekor }\end{array}$ & $\begin{array}{c}160-200 \text { liter } \\
(180 \text { liter })\end{array}$ & $\begin{array}{c}4800-6000 \text { liter } \\
(5400 \text { liter })\end{array}$ \\
\hline 2 & $\begin{array}{l}\text { Ibu Aslam selaku mitra-2 } \\
\text { memilki sapi produlatif } \\
\text { sebarnyak } 9 \text { ekor dari } 25 \text { ekor } \\
\text { sapi seluruh miliknya dan } \\
\text { mampu menghasilkan antara } 5 \text {. } \\
10 \text { liter per ekor }\end{array}$ & $\begin{array}{c}60-80 \text { liter } \\
(70 \text { liter) }\end{array}$ & $\begin{array}{l}1800-2400 \text { liter } \\
(2100 \text { liter })\end{array}$ \\
\hline & Rata-rata Produksi & 125 liter & 3750 liter \\
\hline
\end{tabular}

Dengan asumsi harga 1 liter susu segar berkisar Rp10.000,- yang dijual ke pedagang STMJ atau sebesar $\mathrm{Rp}$ 8.000,- yang dijual ke agen, maka pemasukan pendapatan per bulan usaha mitra-1 berkisar Rp 43.200.000,- hingga Rp 54.000.000,- atau rata-rata sebesar $\mathrm{Rp}$ 48.600.000,-; sedangkan pendapatan per bulan usaha mitra-2 berkisar Rp 16.200.000,- hingga Rp 21.600.000,- atau rata-rata sebesar Rp 18.900.000,- .Adapun biaya pakan dan tenaga kerja, dengan rincian sebagai berikut :

\begin{tabular}{|c|c|c|c|}
\hline No. & Uraian & Biaya Harian & Biaya Bulanan \\
\hline \multirow[t]{6}{*}{1} & $\begin{array}{l}\text { Bapal. Tbu Mas ud selaku mitra-1 } \\
\text { memilliki } 2,5 \text { orang Tenaga kerja yang } \\
\text { bertugas sebagai pemelihara bewan, } \\
\text { kebersihan kandang, pemerah susu. }\end{array}$ & & 3.750 .000 \\
\hline & 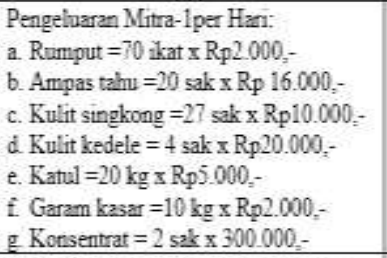 & $\begin{array}{r}140.000 \\
320.000 \\
270.000 \\
80.000 \\
100.000 \\
20.000\end{array}$ & $\begin{array}{r}4.200 .000 \\
9.600 .000 \\
8.100 .000 \\
2.400 .000 \\
3.000 .000 \\
500.000 \\
600.000\end{array}$ \\
\hline & Pengeluaran biaya pakan dan tenaga & & 32250.000 \\
\hline & Biaya penyusutan $(10 \%$ ) & & 3.225 .000 \\
\hline & Total pengeluaran & & 35.475 .000 \\
\hline & \multicolumn{2}{|c|}{ Pendapatan Bersib bulan $=R p 48.600 .000-R p 35.475 .000$} & $13.125 .000,-$ \\
\hline
\end{tabular}

\begin{tabular}{|c|c|c|c|}
\hline No. & Uraian & Biaya Harian & Biaya Bulanan \\
\hline \multirow[t]{5}{*}{2} & $\begin{array}{l}\text { Ibu Aslam selaku mitra-2 } \\
\text { memiliki } 1,5 \text { orang Tenaga } \\
\text { kerja yang bertugas sebagai } \\
\text { pemelihara hewan, kebersihan } \\
\text { kandang, pemerah susu. }\end{array}$ & & 2.250 .000 \\
\hline & 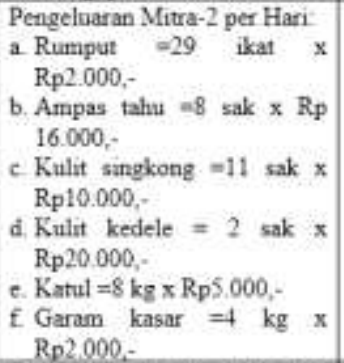 & $\begin{array}{r}58.000 \\
128.000 \\
110.000 \\
40.000 \\
40,000 \\
8.000\end{array}$ & $\begin{array}{r}1.740 .000 \\
3.8+0.000 \\
3.300 .000 \\
1.200 .000 \\
1.200 .000 \\
240.000\end{array}$ \\
\hline & $\begin{array}{l}\text { Pengeluaran biaya pakan dan } \\
\text { tenaga }\end{array}$ & & 13.770 .000 \\
\hline & Biaya penyusutan $(10 \%)$ & & 1377,000 \\
\hline & Total pengeluaran & & 15.147 .000 \\
\hline & $\begin{array}{l}\text { Pendapatan Bersih/bulan }=\operatorname{Rp} 1 \\
\text { Rp15.147.000 }\end{array}$ & $00,000-$ & 3.753 .000 \\
\hline
\end{tabular}




\subsubsection{Dampak Implementasi Teknologi Tepat Guna}

Adapun implementasi adanya blog internet sebagai upaya peningkatan akses pemasaran produk susu segar bagi mitra menunjukkan gejala peningkatan akses di dalam pemasaran susu segar, sehingga berdampak pada kemudahan dan kecepatan penjualan hingga $40 \%$ dan Tim PPM yakin akan terus meningkat dan makin dikenal oleh masyarakat konsumen. Tim sangat berharap bahwa adanya pendampingan dan advokasi terhadap usaha mitra melalui teknologi tepat guna yaitu perbaikan sistem pemasaran dan informasi produk melalui jaringan blog internet, secara perlahan usaha kedua mitra dapat ditingkatkan produktifitasnya artinya kondisi ke depan menunjukkan bahwa konsumen memiliki variasi pilihan dengan memanfaatkan jasa layanan antar ke rumah konsumen dengan akses blog internet. Tim PPM meyakini bahwa pendapatan mitra akan bergerak naik karena indikasi permintaan susu segar semakin meningkat seiring dengan tingkat kesukaan dan kemudahan layanan bagi konsumen dan peningkatan kesejahteraan mitra atas peluang pemasaran atau jaringan bisnis yang bisa diakses melalui jejaring sosial (blog internet) yang makin besar.

Pemberian advokasi oleh Tim selama kegiatan PPM dalam menangani limbah cair peternakan dengan membangun bak/kolam berjenjang juga mampu menggugah kesadaran mitra untuk peduli dan tidak mencemari pada lingkungan sekitar karena selama ini air limbah peternakan secara langsung dibuang ke sungai tanpa ada treatment lebih dulu sehingga peluang mencemari sungai atau lingkungan sekitar demikian besar, pada hal usaha tersebut berada di lokasi pemukiman padat penduduk (sebagaimana gambar 5).

Dengan adanya implementasi teknologi tepat guna tersebut diatas baik berupa pembangunan bak/kolam berjenjang dalam penanganan limbah peternakan, peningkatan manajemen pemasaran baik berupa akses informasi melalui blog internet yang memungkinkan membuka peluang pesanan susu segar bagi konsumen yang makin banyak, sehingga upaya ini diharapkan dapat meningkatkan penjualan, sehingga akan berdampak pada meningkatnya pendapatan dan kesejahteraan mitra.

Selanjutnya semakin meningkatkan produktivitas usaha peternakan akan berdampak sosial pada naiknya kesejahteraan dan pendapatan mitra. Bila pendapatan per kapita naik, ini akan meningkatkan standard hidup warga Kelurahan Bendul Merisi khususnya peternak sapi perah, selanjutnya akan berpengaruh pada perbaikan standard pendidikan bagi anak-cucunya. Membaiknya kualitas sumber daya manusia khusunya UKM-UKM peternak ini akan berpengaruh terhadap kemajuan usaha-usaha produktifnya karena lebih terdidik, terlatih serta mampu mengembangkan pola pikir yang berorientasi bisnis, sehingga ke depan kemandirian bangsa dapat diwujudkan dengan semakin banyaknya UKM-UKM produktif.

Oleh sebab itu adanya Iptek Bagi Masyarakat (IbM) sangat mendukung penyelesaian masalah peternak sapi perah tersebut. Peluang usaha mikro ini cukup menjanjikan prospeknya karena dibutuhkan sedikit sentuhan teknologi tepat guna agar kendala yang selama menghambat usaha penjualan susu segar maupun pencemaran lingkungan bisa diatasi dengan baik. Disinilah peran Universitas Merdeka Surabaya melalui tim pengabdi membantu memberikan program pendampingan dan advokasi untuk mewujudkan harapan menjadi kenyataan bagi kelompok peternak sapi perah di Bendul Merisi Kelurahan Bendul Merisi Kecamatan Wonocolo Kota Surabaya

\section{KESIMPULAN}

Berdasar hasil yang dicapai maka dapat disimpulkan sebagai berikut :

1. Penggunaan paket teknologi tepat guna berupa pembangunan bak/kolam berjenjang di Kelurahan Bendul Merisi Kecamatan Wonocolo Surabaya mampu meningkatkan kesadaran mitra untuk peduli lingkungan dengan tidak membuang limbah cair peternakan secara langsung ke sungai.

2. Penggunaan akses internet dalam bentuk blogspot mampu meningkatkan akses pemasaran produk susu segar secara lebih luas (hingga 40\%) karena dapat dipesan oleh konsumen melalui jaringan tersebut.

3. Peningkatan peluang bagi berkembangnya tenaga terdidik baik bagi pelaku usaha (peternak) maupun tenaga pekerja, sehingga mendukung produktifitas usaha dan kesejahteraan masyarakat sekitar

\section{REFERENSI}

Charles RT dan Hariono, B. 1991. Pencemaran Lingkungan oleh Limbah Peternakan dan Pengelolaannya. Bull.FKH-UGM Vol. X: 2 . Direktorat Pengembangan Laboratorium Rujukan dan Pengelolaan Data, 1994. Standar 
Nasional Indonesia : Pengujian Kualitas Air Sumber dan Limbah Cair. BAPEDAL. Jakarta.

Dinas Peternakan Propinsi Jawa Timur. http://disnak.jatimprov.go.id/web

Fianda Revina Widyastuti1, Purwanto2, Hadiyanto. 2013. Upaya Pengelolaan Lingkungan Usaha Peternakan Sapi di Kawasan Usahatani Terpadu. Prosiding Seminar Nasional Pengelolaan Sumber Daya Alam dan Lingkungan. Pangkal Pinang.

Irma Anshari, 2014. Penanganan Limbah Cair. Witasharer.blogspot.com
Prasetyo, S dan Padmono, J. 1993. Alternatif Pengelolaan Limbah Cair dan Padat RPH.

SK Menteri Pertanian, 1991. SK Mentan No. 273/Kpts/RC410/1991 tentang Batasan Usaha Peternakan yang harus Melakukan Evaluasi Lingkungan. Departemen Pertanian . Jakarta.

Sofyadi Cahyan, 2003. Konsep Pembangunan Pertanian dan Peternakan Masa Depan. Badan Litbang Departemen Pertanian. Bogor.

Sihombing D T H. 2000. Teknik Pengelolaan Limbah Kegiatan/Usaha Peternakan. Pusat Penelitian Lingkungan Hidup Lembaga Penelitian, Institut Pertanian Bogor 